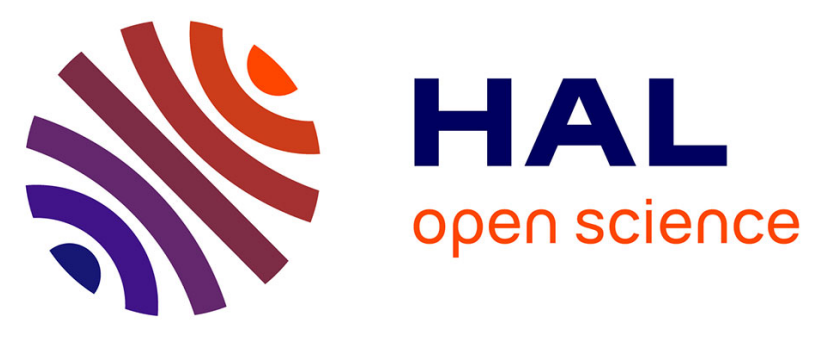

\title{
Chinese Script vs Plate-Like Precipitation of Beta-A19Fe2Si2 Phase in an Al-6.5Si-1Fe Alloy
}

Deni Ferdian, Claudie Josse, Patrick N'Guyen, Nathalie Gey, Nicolas

Ratel-Ramond, Philippe de Parseval, Yannick Thebault, Benoit Malard, Jacques Lacaze, Luc Salvo

\section{To cite this version:}

Deni Ferdian, Claudie Josse, Patrick N'Guyen, Nathalie Gey, Nicolas Ratel-Ramond, et al.. Chinese Script vs Plate-Like Precipitation of Beta-A19Fe2Si2 Phase in an Al-6.5Si-1Fe Alloy. Metallurgical and Materials Transactions A, 2015, 46A (7), pp.2814-2818. 10.1007/s11661-015-2917-1 . hal-01213184

\author{
HAL Id: hal-01213184 \\ https://hal.science/hal-01213184
}

Submitted on 8 Jan 2018

HAL is a multi-disciplinary open access archive for the deposit and dissemination of scientific research documents, whether they are published or not. The documents may come from teaching and research institutions in France or abroad, or from public or private research centers.
L'archive ouverte pluridisciplinaire HAL, est destinée au dépôt et à la diffusion de documents scientifiques de niveau recherche, publiés ou non, émanant des établissements d'enseignement et de recherche français ou étrangers, des laboratoires publics ou privés. 


\section{Open Archive TOULOUSE Archive Ouverte (OATAO)}

OATAO is an open access repository that collects the work of Toulouse researchers and makes it freely available over the web where possible.

This is an author-deposited version published in : http://oatao.univ-toulouse.fr/ Eprints ID : 18098

To link to this article : DOI:10.1007/s11661-015-2917-1

URL : http://dx.doi.org/10.1007/s11661-015-2917-1

To cite this version : Ferdian, Deni $\stackrel{\varpi}{\varpi}$ and Josse, Claudie Nguyen, Patrick and Gey, Nathalie and Ratel-Ramond, Nicolas and de Parseval, Philippe and Thebault, Yannick $\bullet$ and Malard, Benoît and Lacaze, Jacques Precipitation of Beta-Al9Fe2Si2 Phase in an Al-6.5Si-1Fe Alloy. (2015) Metallurgical and Materials Transactions A, vol. 46 ( $\left.\mathrm{n}^{\circ} 7\right)$. pp. 2814-2818. ISSN 1073-5623

Any correspondence concerning this service should be sent to the repository administrator: staff-oatao@,listes-diff.inp-toulouse.fr 


\section{Chinese Script vs Plate-Like Precipitation of Beta- $\mathrm{Al}_{9} \mathrm{Fe}_{2} \mathrm{Si}_{2}$ Phase in an Al-6.5Si-1Fe Alloy}

\author{
DENI FERDIAN, CLAUDIE JOSSE, \\ PATRICK NGUYEN, NATHALIE GEY, \\ NICOLAS RATEL-RAMOND, \\ PHILIPPE DE PARSEVAL, \\ YANNICK THEBAULT, BENOIT MALARD, \\ JACQUES LACAZE, and LUC SALVO
}

The microstructure of a high-purity Al-6.5Si-1Fe (wt pet) alloy after solidification at various cooling rates was investigated. In most of the cases, the monoclinic beta- $\mathrm{Al}_{9} \mathrm{Fe}_{2} \mathrm{Si}_{2}$ phase was observed as long and thin lamellae. However, at a very slow cooling rate, Febearing precipitates with Chinese script morphology appeared together with lamellae. Further analysis showed all these Chinese script precipitates correspond also to the monoclinic beta phase. This finding stresses that differentiating second phases according to their shape may be misleading.

DOI: $10.1007 / \mathrm{s} 11661-015-2917-1$

Aluminum-silicon alloys are the most common aluminum casting alloys produced due to their fluidity characteristic, mechanical, and light weight properties. In some commercial grades, minor alloying elements are

DENI FERDIAN, formerly PhD Student with the CIRIMAT, Université de Toulouse, ENSIACET, CS 44362, 31030 Toulouse Cedex 4, France, is now Lecturer with the Department of Metallurgy and Materials Engineering, Universitas Indonesia, Kampus Baru UI, Depok, 16424, Indonesia. Contact e-mail: deni@metal.ui.ac.id CLAUDIE JOSSE, Research Associate, YANNICK THEBAULT, Research Associate, BENOIT MALARD, Assistant Professor, and JACQUES LACAZE, Senior Scientist, are with the CIRIMAT, Université de Toulouse, ENSIACET. PATRICK NGUYEN, PhD Student, is with the CNES, 18 Avenue Edouard Belin, 31400 Toulouse, France. NATHALIE GEY, Research Scientist, is with the LEM3, UMR CNRS 7239, Université de Lorraine, 57045 Metz, France. NICOLAS RATEL-RAMOND, Research Associate, is with the CEMES, 29 Rue Jeanne Marvig, 31055 Toulouse Cedex 4, France. PHILIPPE DE PARSEVAL, Research Associate, is with the GET, OMP, UMR 5563, 14 Avenue E. Belin, 31400 Toulouse, France. LUC SALVO, Professor, is with the Universite de Grenoble Alpes, SIMAP, 38000 Grenoble, France. sometimes added to enhance their specific properties. Because of the increased use of scraps for economic reasons, alloying additions as well as impurities get gradually accumulated with recycling. ${ }^{[1]}$ Iron is one of the main impurities found in aluminum alloys and this has led to numerous studies on Al-rich Al-Si-Fe alloys.

Review of the Al-Fe-Si system can be tracked back to the work by Gwyer and Philips ${ }^{[2]}$ which showed the liquidus projection of the system. This early work was later complemented by the extensive study conducted by Takeda and Mutuzaki. ${ }^{[3]}$ The most prominent review of the system is due to Rivlin and Raynor ${ }^{[4]}$ who assessed the literature published until early 80 's and to Gosh ${ }^{[5]}$ who updated it with more recent finding. According to the stable Al-Si-Fe phase diagram, Al-rich alloys could present precipitation of the following intermetallic phases: monoclinic $\Theta-\mathrm{Al}_{13} \mathrm{Fe}_{4}(C 2 / m ; a=15.49 \AA$, $b=8.08 \AA, c=12.47 \AA, \beta=107.4 \mathrm{deg}),{ }^{[6]}$ hexagonal $\alpha_{\mathrm{h}}-\mathrm{Al}_{8} \mathrm{Fe}_{2} \mathrm{Si}\left(P 6_{3} / m m c ; a=12.40 \AA, c=26.23 \AA\right)^{[7]}$, and monoclinic $\beta-\mathrm{Al}_{9} \mathrm{Fe}_{2} \mathrm{Si}_{2} \quad(m C 52 ; a=6.16 \AA$, $b=6.17 \AA, c=20.81 \AA, \beta=90.42 \mathrm{deg}){ }^{[8]}$ Chemical analyses showed that 1 to 2 wt pct Si can enter in theta, that the alpha phase has a range of chemical composition (wt pct) of 30 to 36 pct Fe and 6 to 11 pct Si, and that the beta phase has a range of chemical composition of 25 to 30 pct $\mathrm{Fe}$ and 12 to 15 pct Si. ${ }^{[9]}$

In earlier literature, alpha phase was considered as cubic which can be seen in works by Phragmen ${ }^{[10]}$ and Cooper. ${ }^{[1]}$ However, investigation by Munson ${ }^{[12]}$ showed that addition of transition elements such as $\mathrm{Mn}$ replaces the hexagonal $\alpha_{\mathrm{h}}-\mathrm{Al}_{8} \mathrm{Fe}_{2} \mathrm{Si}$ phase by the $\alpha-\mathrm{Al}_{15}(\mathrm{Fe}, \mathrm{Mn})_{3} \mathrm{Si}_{2}$ with a cubic structure isomorph to the $\mathrm{Al}_{8} \mathrm{Mn}_{2} \mathrm{Si}$ phase of the Al-Mn-Si system. Further work by Zheng et al. ${ }^{[13]}$ and $\mathrm{Kral}^{[14]}$ also showed that the alpha phase has a cubic crystal structure in $\mathrm{Al}-\mathrm{Fe}-\mathrm{Si}$ alloys containing some manganese. Consequently, the hexagonal crystal structure is considered as the structure of alpha phase in high-purity Al-Fe-Si ternary alloys. Note that the use of the same Greek letter for different phases is very unfortunate, this has led to errors in the past and still leads to ambiguities in present literature.

The beta phase is considered to have a monoclinic crystal structure as shown in the studies by Romming et al. ${ }^{[8]}$ Phragmen, ${ }^{[10]}$ and Hansen et al. ${ }^{[15]}$ However, a conflicting result was obtained by Zheng ${ }^{[13]}$ and Carpenter and Page ${ }^{[16]}$ who indicated the beta phase as orthorhombic. Later work by Hwang et al. ${ }^{[17]}$ argues that this latter hypothesis was a misperception of crystal structure, so that the monoclinic structure will be accepted here.

In a large part of the related technical and scientific papers, intermetallic phases in aluminum alloys are identified by means of their morphology in 2D metallographic sections. Thus, researchers characterized the morphology of alpha phase as Chinese script and that of beta phase as needle-like. Further development by using deep etching and scanning electron microscopy analysis 
showed that the beta phase actually has a plate-like structure. Dinnis et al. ${ }^{[18]}$ who performed 2D serial sectioning to build 3D images were the first to show this plate-like precipitates are interconnected. However, as pointed out by Kral, ${ }^{[14]}$ phase identification based on 2D morphology may be erroneous and the present paper shows an example where such an error could be possible.

Previous studies ${ }^{[19,20]}$ on the effect of cooling rate on the morphology of beta phase in a high-purity A1-6.5Si$1 \mathrm{Fe}$ alloy showed Chinese script precipitates appearing in samples cooled at $0.2 \mathrm{~K} / \mathrm{min}$. Similar Chinese script precipitates were also reported by Mikolajczak and Ratke $^{[21]}$ on an Al-7Si-1Fe alloy. However, this observation would not comply with the solidification path calculated for these alloys, ${ }^{[20]}$ if it were assumed this morphology was associated with the hexagonal $\alpha_{\mathrm{h}}-\mathrm{Al}_{8} \mathrm{Fe}_{2} \mathrm{Si}$ phase. An attempt to study further such Chinese script precipitation is presented in this work.

An Al-6.5Si-1Fe (in wt pet) synthetic alloy was cast by Hydro Aluminum Deutschland $\mathrm{GmBH}$ from high-purity metals and then prepared into 10-mm rods. Samples were finally machined into rods of approximately $3.9 \mathrm{~mm}$ in diameter and $5 \mathrm{~mm}$ in height, and subjected to differential thermal analysis (DTA) using a SETARAM-SETSYS apparatus. DTA experiments were carried out under a low argon flow after purging the cell. They consisted of heating the sample up to $923 \mathrm{~K}\left(650{ }^{\circ} \mathrm{C}\right)$ when it was fully liquid, holding it at that temperature for 10 minutes for homogenization, and finally cooling it down to room temperature at a rate of $0.02,0.05$, or $0.1 \mathrm{~K} / \mathrm{min}$. The samples were then prepared by standard method for metallographic examination. Characterization of the intermetallic precipitates was made using optical microscopy (Nikon Eclipse MA 200) and scanning electron microscopy (SEM LEO $435 \mathrm{VP}$ ) equipped with an energy dispersive spectrometer (EDS). Electron probe micro-analysis (EPMA) was also conducted on selected particles with a CAMECA SX50. Deep etching was performed on some samples with a 10 pct $\mathrm{HCl}$ solution for 30 to 40 minutes. The acid dissolves most of the primary and eutectic Al-rich solid solution (Al) and leaves the eutectic silicon and iron-rich particles in the interdendritic region.

Further analysis for crystal structure identification was performed by X-ray analysis using a micro-XRD instrument (Bruker Advance D8 equipped with micro beam focus) and by Electron Back Scattering Diffraction (EBSD) with an Oxford Instrument (AZTecHKL software) attached to a SEM JEOL 7001F. XRD used a $\mathrm{Cu}-\mathrm{K} \alpha$ radiation $(\lambda=1.54060 \AA)$ with source parameters at $40 \mathrm{~mA}$ and $40 \mathrm{kV}$. Diffraction patterns were acquired with a fast linear detector between 15 and $80 \mathrm{deg}$ in $2 \theta$ with a step of $0.03 \mathrm{deg}$ and exposure area (slit size) of $100 \times 100 \mu \mathrm{m}^{2}$. The selection of the diffracting area is made by means of a system consisting of a camera and a laser spot, aligned with the X-ray beam.

Micrographs in Figure 1 illustrate the microstructure obtained for each of the three cooling rates investigated. It consists of dendrites of the (Al) phase (light contrast), long plates of beta phase (gray contrast) which appear partly embedded in the dendrites, and a relatively fine eutectic where the dark lamellae are silicon. This agrees

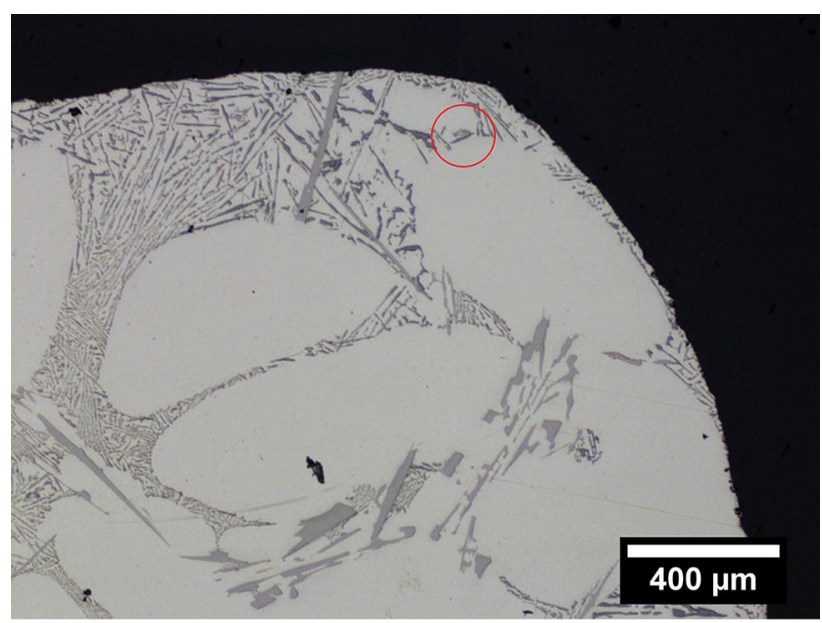

(a)

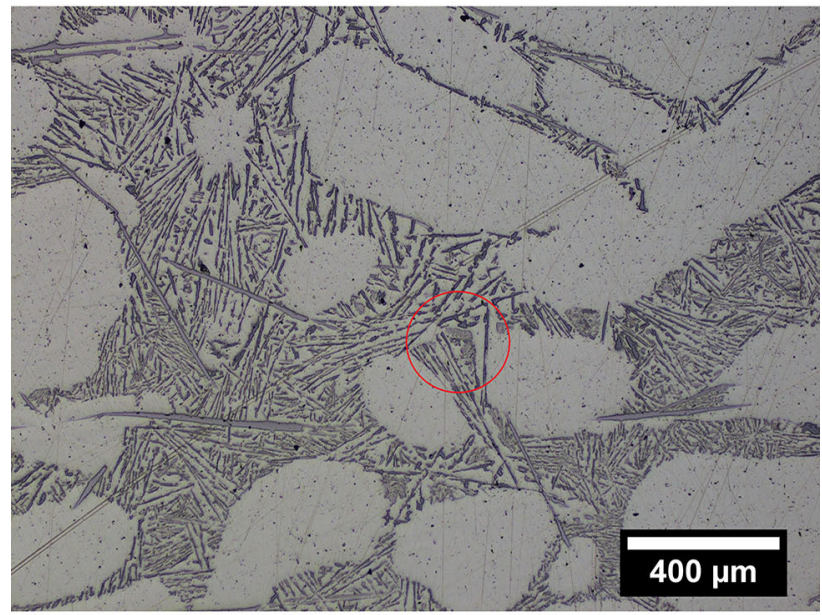

(b)

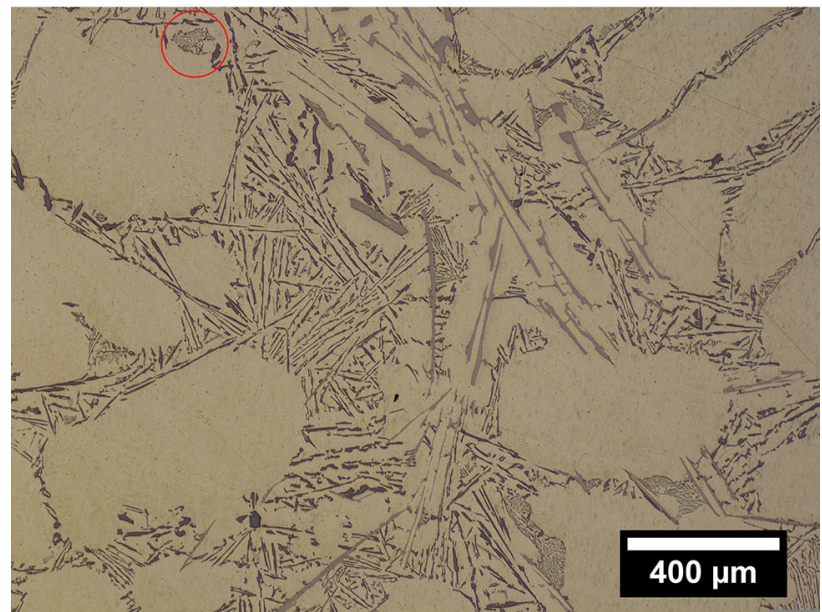

(c)

Fig. 1-Micrographs of DTA samples for various cooling rates $(a)$ $0.02 \mathrm{~K} / \mathrm{min}$, (b) $0.05 \mathrm{~K} / \mathrm{min}$, and $(c) 0.1 \mathrm{~K} / \mathrm{min}$.

with the solidification path expected for the investigated alloy, namely primary deposition of (Al), followed by eutectic growth of (Al) and beta, and solidification completion at the invariant ternary (Al)-beta-Si eutectic. ${ }^{[19]}$ 


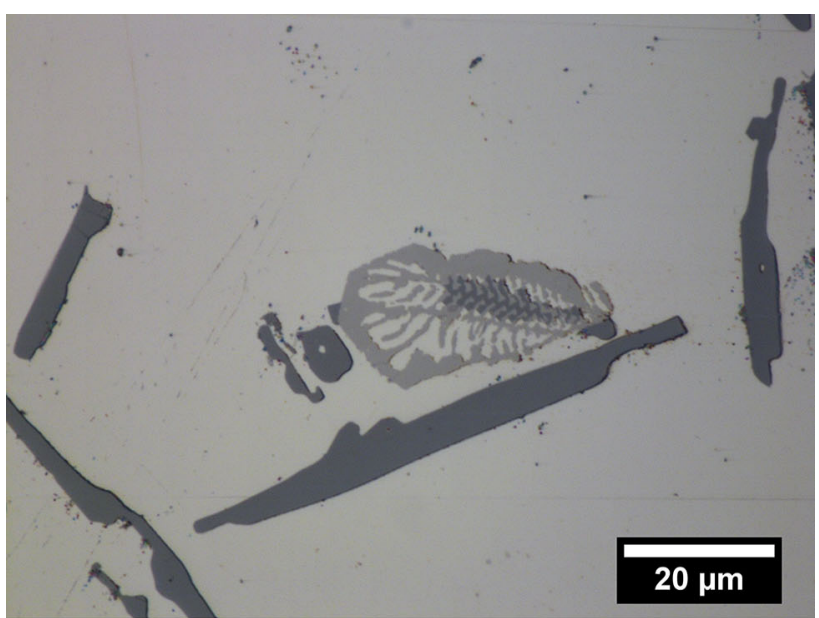

(a)

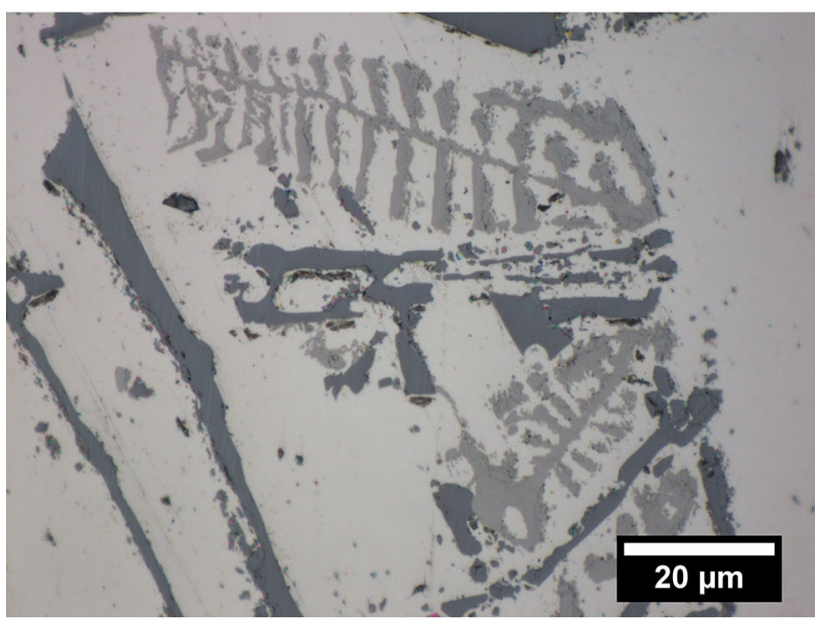

(b)

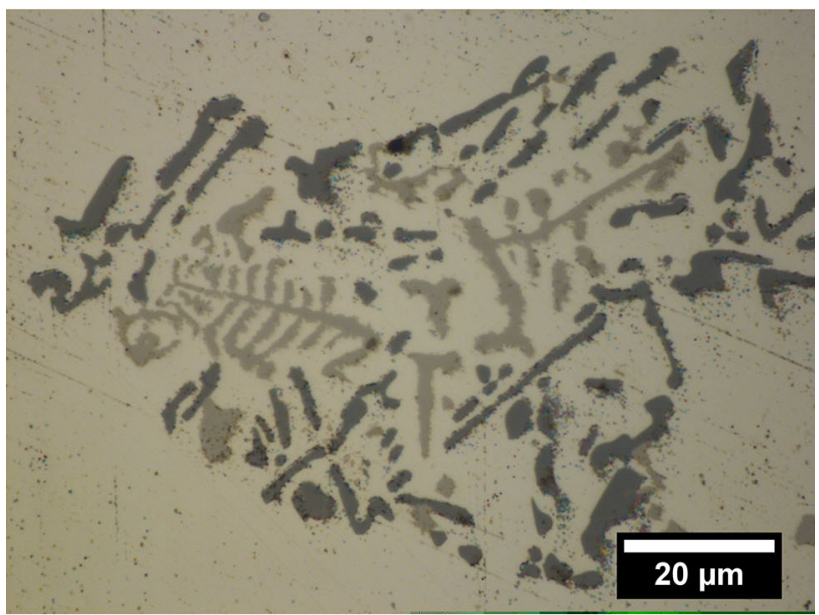

(c)

Fig. 2-Micrographs of the Chinese script precipitates seen in the circled areas of Fig. 1. (a) $0.02 \mathrm{~K} / \mathrm{min}$, (b) $0.05 \mathrm{~K} / \mathrm{min}$, and $(c)$ $0.1 \mathrm{~K} / \mathrm{min}$.

In all these samples, Chinese script precipitates were observed such as those circled in the micrographs in Figure 1 and are shown enlarged in Figure 2. At a higher cooling rate than $2 \mathrm{~K} / \mathrm{min}$, such precipitates were not observed. ${ }^{[20]}$ The size of the script precipitates varies

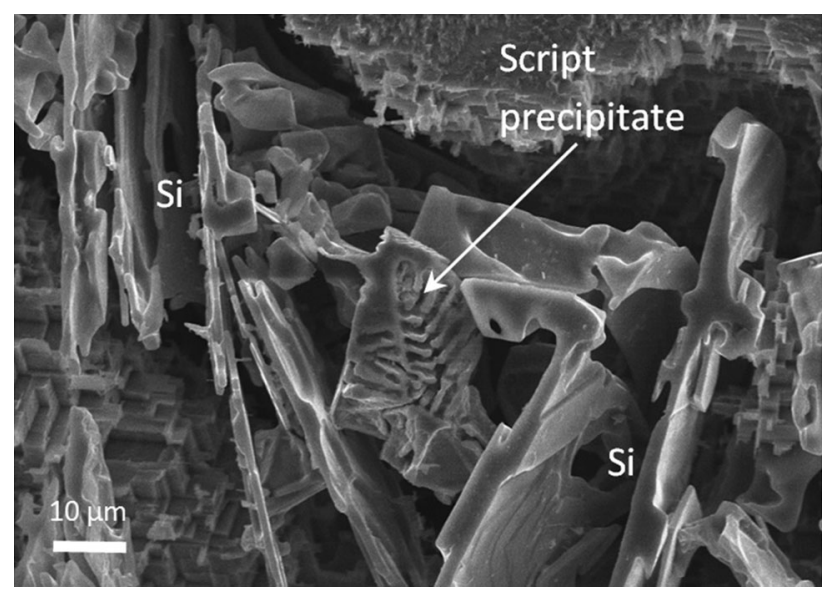

Fig. 3-Script precipitate (white arrow) close to eutectic silicon after deep etching.

Table I. EDS and EPMA Results of Script Phase in a Sample Cooled at $0.1 \mathrm{~K} / \mathrm{min}$

\begin{tabular}{lcccc}
\hline & & \multicolumn{3}{c}{$\begin{array}{c}\text { Chemical Composition } \\
\text { (Wt Pct) }\end{array}$} \\
\cline { 3 - 5 } $\begin{array}{l}\text { Analysis } \\
\text { Method }\end{array}$ & Test Location No. & $\mathrm{Al}$ & $\mathrm{Si}$ & $\mathrm{Fe}$ \\
\hline EDS & 1 & 58.8 & 15.3 & 25.9 \\
& \multirow{2}{*}{2} & 58.3 & 15.6 & 26.1 \\
& & 58.6 & 15.1 & 26.3 \\
& \multirow{2}{*}{ average } & 59.5 & 15.1 & 25.4 \\
& 1 & 58.8 & 15.3 & 25.9 \\
& 2 & 55.8 & 15.5 & 28.7 \\
& 2 & 59.8 & 14.3 & 25.9 \\
& & 61.4 & 14.2 & 24.4 \\
& & 56.5 & 15.5 & 28 \\
& & 58.4 & 14.9 & 26.7 \\
\hline
\end{tabular}

but overall was less than $100 \mu \mathrm{m}$ in length in $2 \mathrm{D}$ section, and in fact quite similar to the length of the silicon lamellae. The appearance of script precipitates is dispatched in interdendritic regions and can be observed in the center as well as outer part of the sample. In most cases, the microstructure features of these so-called Chinese script precipitates showed a fishbone or skeleton appearance as seen in the enlarged images of Figure 2.

If the Chinese script precipitates had formed first as hexagonal alpha phase, one would expect from the Al-Fe-Si ternary phase diagram they then transformed to monoclinic beta by a peritectic reaction during solidification. No trace of such a peritectic transformation could be observed.

From metallographic examination, we could also notice that no or very few plate-like beta precipitates could be detected near script precipitates. Deep etching of the samples showed nicely the proximity of script precipitates with silicon lamellae as illustrated in Figure 3. Finally, DTA records showed no specific arrest that could be related to the separate appearance of these precipitates. ${ }^{[20]}$ All these observations lead to conclude that these precipitates form during the final 


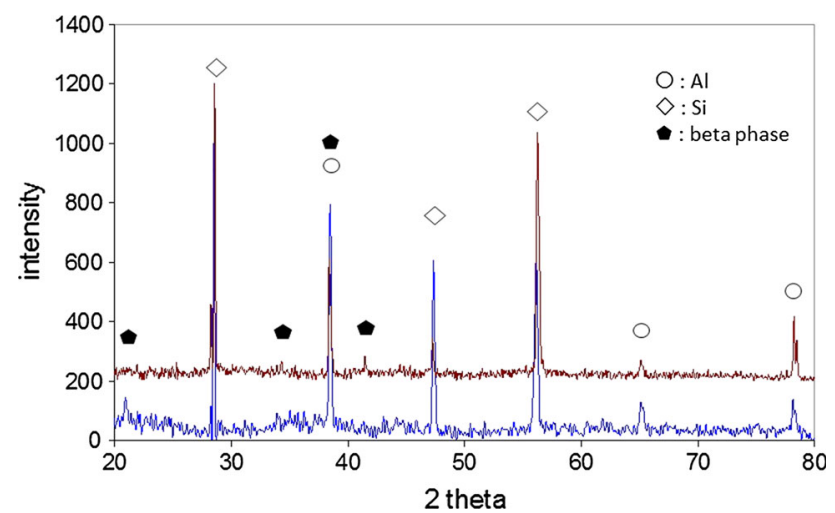

Fig. 4-XRD patterns of two measurements showing peaks of (Al), $\mathrm{Si}$ and beta phase.

invariant eutectic with simultaneous precipitation of (Al) and $\mathrm{Si}$. A clear proof of this is that the three phases may grow internested as apparent in Figure 2(a).

EDS analysis of the Chinese script precipitates was conducted in various locations of a sample cooled at $0.1 \mathrm{~K} / \mathrm{min}$. Analysis showed the total of element contents ranging between 94 and 98 pct, therefore the data were normalized. The results revealed that these precipitates have a similar chemical composition to platelike beta phase with 25.9 wt pct Fe and 15.3 wt pct $\mathrm{Si}$ on average as seen in Table I. EPMA results obtained on the same sample also do not significantly differ from EDS results with 26.7 wt pet $\mathrm{Fe}$ and 14.9 wt pet $\mathrm{Si}$ on average (Table I). The corresponding $\mathrm{Fe} / \mathrm{Si}$ ratio around 1.8 is well in the range reported for beta phase. ${ }^{[9]}$

To obtain further support for this conclusion, micro $\mathrm{X}$-ray analysis and EBSD were carried out. Two microXRD records plotted in Figure 4 were performed on the precipitate in Figure 2(b) showing four major peaks between 25 and $60 \mathrm{deg}$ in $2 \theta$. Based on a structural database search, those peaks appear to correspond to $\mathrm{Al}$ (111) and Si (111), (220) and (311), as indexed with JCPDS cards no. 00-004-0787 and 00-027-1402, respectively. Very small additional peaks could be detected, which are marked with solid symbols in Figure 4 and could be indexed with JCPDS card file no. 00-054-0376 which corresponds to beta phase. It was verified that these peaks could not be indexed as hexagonal alpha phase (JCSPDS card number 00-041-0894).

Further phase identification of Chinese script precipitates was performed by EBSD. Figure 5 gives a typical examination with a script precipitate shown in Figure 5(a) and its Kikuchi pattern in Figure 5(b). This pattern was unambiguously indexed as monoclinic $\beta-\mathrm{Al}_{9} \mathrm{Fe}_{2} \mathrm{Si}_{2}$. It was the only phase of a user pre-selected phase list (consistent with this alloy) that offered a high number of band matching between experimental and simulated patterns, while indexing could not at all match for $\alpha_{\mathrm{h}}-\mathrm{Al}_{8} \mathrm{Fe}_{2} \mathrm{Si}$. Figure 5(c) shows the superposition of the experimental and simulated patterns. Some experimental bands are not reproduced in the simulation,

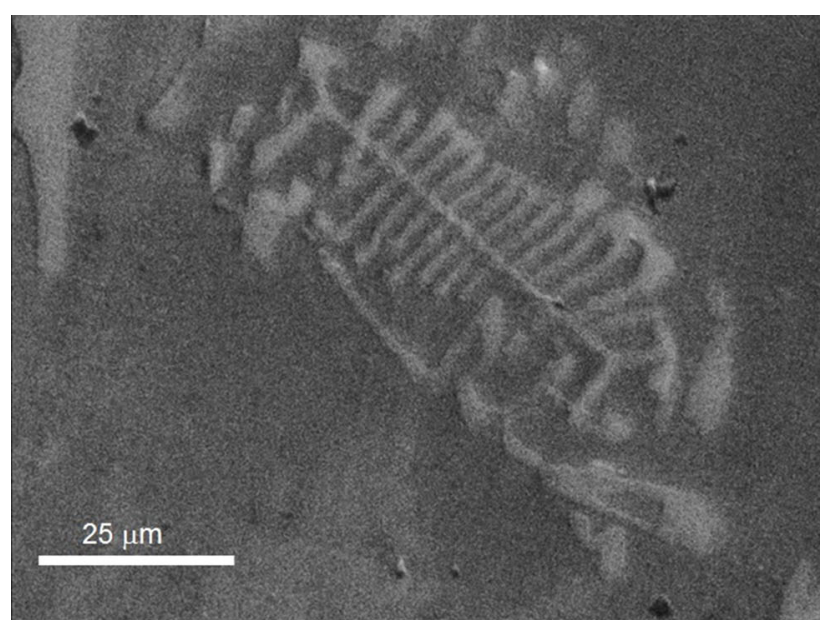

(a)

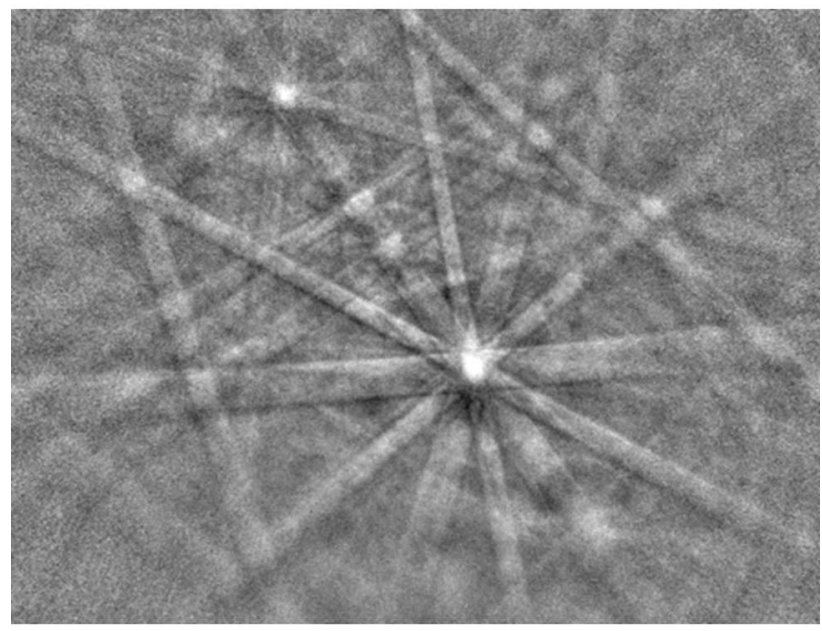

(b)

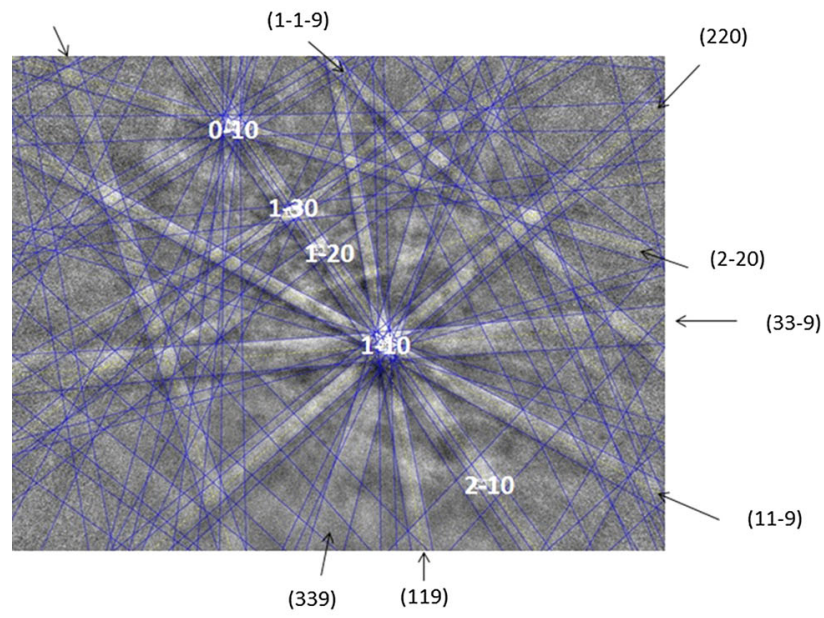

(c)

Fig. 5-EBSD pattern obtained from a script precipitate. (a) Micrograph, (b) Kikuchi pattern, $(c)$ indexed pattern with 50 reflectors. The EBSD pattern is indexed according to the monoclinic $\beta-\mathrm{Al}_{9} \mathrm{Fe}_{2} \mathrm{Si}_{2}$, with the zone axes indicated within the figure and the trace of the planes along the outer border of the pattern. 
it was checked that they belong to the Kikuchi pattern of the (Al) matrix surrounding the Chinese script precipitate.

In conclusion, characterization of the script phase found in an $\mathrm{Al}-6.5 \mathrm{Si}-1 \mathrm{Fe}$ synthetic alloy shows that it corresponds to the beta $\mathrm{Al}_{9} \mathrm{Fe}_{2} \mathrm{Si}_{2}$ phase based on the monoclinic crystal structure and chemical analysis. Although the microstructure appears with clear script or fishbone feature, it could definitely not be associated with the hexagonal alpha $\mathrm{Al}_{8} \mathrm{Fe}_{2} \mathrm{Si}$ phase. This finding shows that differentiation of second phases in $\mathrm{Al}-\mathrm{Si}$ alloys based only on morphology can be ambiguous.

Financial support from the European Space Agency (Contract \#4200014347) through the MICAST program was greatly appreciated.

\section{REFERENCES}

1. J.A.S. Green: Aluminum Recycling and Processing for Energy Conservation and Sustainability, ASM International, Materials Park, OH, 2007.

2. A.G.C. Gwyer and H.W.L. Phillips: J. Inst. Met., 1927, vol. 38, pp. $35-44$.

3. H.P. Takeda and K. Mutuzaki: Tetsu to Hagane, 1940, vol. 26, pp. 335-61.
4. V.G. Rivlin and G.V. Raynor: Int. Met. Rev., 1981, vol. 26, pp. 133-52.

5. G. Gosh: in Ternary Alloy Systems: Phase Diagrams, Crystallographic and Thermodynamic Data, Vol. 11, Subvolume D 'Iron Systems', of Landolt-Börnstein - Group IV Physical Chemistry, G. Effenberg and S. Ilyenko, eds., pp. 184-266.

6. P.J. Black: Acta Crystallogr., 1955, vol. 8, pp. 43-48.

7. K. Robinson and P.J. Black: Philos. Mag., 1953, vol. 44, pp. 139297.

8. C Romming, V Hansen, and J Gjonnes: Acta Crystallogr. Sect. B Struct. Crystallogr. Crys. Chem., 1994, vol. B50 (3), pp. 307-12.

9. L.F. Mondolfo: Aluminium Alloys, Structure and Properties, Butterworths, London, 1976.

10. G. Phragmen: J. Inst. Met., 1950, vol. 77, pp. 489-552.

11. M. Cooper: Acta Crystallogr., 1976, vol. 23, pp. 1106-07.

12. D. Munson: J. Inst. Met., 1967, vol. 95, pp. 217-19.

13. J.G. Zheng, R. Vincent, and J.W. Steeds: Philos. Mag. A., 2000, vol. 80, pp. 493-500.

14. M.V. Kral: Mater. Lett., 2005, vol. 59, pp. 2271-76.

15. V. Hansen, B. Hauback, M. Sundberg, C. Romming, and J. Gjonnes: Acta Crystallogr., 1998, vol. 54B, pp. 351-57.

16. G.J.C. Carpenter and Y. Le Page: Scripta Metall. Mater., 1993, vol. 28 , pp. $733-36$.

17. J.Y. Hwang, H.W. Doty, and M.J. Kaufman: Philos. Mag., 2008, vol. 88, pp. 607-19.

18. C.M. Dinnis and J.A. Taylor: Scripta Mater., 2005, vol. 53, pp. $955-58$.

19. D. Ferdian, B. Suharno, B. Duployer, C. Tenailleau, L. Salvo, and J. Lacaze: Trans. Indian Inst. Met., 2012, vol. 65, pp. 821-25.

20. D. Ferdian: PhD Thesis, Université de Toulouse, INPT, 2014. http://ethesis.inp-toulouse.fr/archive/00002786/01/ferdian.pdf (Extended abstract in French, text in English).

21. P. Mikolajczak and L. Ratke: Intermetallic Phases and Microstructure in AlSi Alloys Influenced by Fluid Flow, Supplemental Proceedings: General Paper Selections, TMS, 2011, vol. 3, pp. $825-32$. 